\title{
Pengaruh komponen fisik dan motivasi latihan terhadap keterampilan bermain sepakbola
}

\author{
Firmansyah Dahlan ${ }^{1 *}$, Rahmad Hidayat ${ }^{1}$, Syahruddin Syahruddin ${ }^{2}$ \\ ${ }^{1}$ Program Studi Pendidikan Jasmani, Pendidikan Jasmani, Fakultas Ilmu Pendidikan Keguruan, \\ Universitas Muhammadiyah Palopo. Jalan Jendral Sudirman Km. 3, Kota Palopo, Indonesia \\ ${ }^{2}$ Fakultas Ilmu Keolahragaan, Universitas Negeri Makassar. Jalan Wijaya Kusuma No.14, Kota \\ Makassar, 90222, Indonesia \\ * Corresponding Author. Email: firmansyahdahlan800@gmail.com
}

\begin{abstract}
Abstrak: Penelitian ini bertujuan untuk menguji pengaruh komponen fisik yakni kelentukan, kelincahan, koordinasi mata-kaki, kecepatan, keseimbangan dan motivasi latihan terhadap keterampilan bermain sepakbola. Berdasarkan sifatnya yang bertujuan untuk menguji (Explanatory) maka penelitian ini menggunakan analisis jalur (path analisis). Variabel independen yaitu kelentukan, kelincahan, koordinasi mata-kaki, dan motivasi latihan, adapun variabel dependen yaitu keterampilan bermain sepakbola (tes teknik dasar passing, dribbling, shooting, jugling, dan heading) yang diakumulasi kedalam nilai T-score. Teknik sampling menggunakan sampel jenuh yaitu seluruh populasi pemain sepakbola UKM Olahraga Sepakbola UM Palopo berjumlah 57 orang. Waktu dan tempat penelitian mengikuti ketentuan WFH (work from home) karena kondisi pandemic dan dipantau secara daring. Analisis data menggunakan uji regresi korelasional. Hasil penelitian memperlihatkan Komponen fisik (kelentukan, kelincahan, koordinasi mata-kaki, kecepatan, keseimbangan) dan motivasi latihan berpengaruh terhadap keterampilan bermain sepakbola. Komponen fisik (kelentukan, kelincahan, koordinasi mata-kaki, kecepatan, keseimbangan) melalui motivasi latihan berpengaruh terhadap keterampilan bermain sepakbola. Penelitian dan pengambilan data dapat dilakukan dapat dilakukan secara daring, tentunya dengan penggunaan dan pengembangan media (e-learning UM Palopo dan Google Form) dan komitmen yang tinggi dari semua pihak.
\end{abstract}

Kata Kunci: komponen fisik, motivasi latihan, sepakbola

\section{The effect of physical ability and training motivation towards soccer skills}

\begin{abstract}
This research examines the effect of flexibility, agility, eye-foot coordination, speed, balance, and training motivation towards soccer skills. Based on its intended nature, which is to examine (Explanatory), this research uses path analysis. The independent variables are flexibility, agility, eye-foot coordination, and training motivation. In contrast, the dependent variables are soccer skills (passing, dribbling, shooting, juggling, and heading), which are accumulated into T-values. The sampling technique uses saturated samples, which is the entire population of Soccer players in UM Palopo.57 people. The time and place of this research followed the WFH provisions (working from home) due to pandemic requirements and was monitored through online. Data analysis was using the correlational regression test. The research results prove that physical abilities (flexibility, agility, eye-foot coordination, speed, balance) and training motivation are strongly related to soccer skills. This research and data collection was conducted and collected by using developing media (UM Palopo e-learning and Google Forms) and high commitment from all parties.
\end{abstract}

Keywords: physical abilities, training motivation, soccer

How to Cite: Dahlan, F., Hidayat, R., \& Syahruddin, S. (2020). Pengaruh komponen fisik dan motivasi latihan terhadap keterampilan bermain sepakbola. Jurnal Keolahragaan, 8(2), 126139. doi:https://doi.org/10.21831/jk.v8i2.32833

\section{PENDAHULUAN}

Universitas Muhammadiyah Palopo merupakan hasil dari penggabungan beberapa sekolah tinggi Muhammadiyah di Kota Palopo pada tahun 2019 dan memiliki Prodi Pendidikan Jasmani pada tahun 
2017. Memasuki era baru menjadi Universitas tentunya membutuhkan banyak pengembangan di berbagai bidang. Melalui penelitian ini diharapkan tercapai pengembangan peningkatan jumlah penelitian dan literatur serta pengembangan Unit Kegiatan Mahasiswa (UKM) berupa sumber informasi baru kepada pembina UKM Olahraga Sepakbola tentang gambaran komponen fisik, motivasi berlatih, dan keterampilan bermain sepakbola serta pola hubungan ketiga faktor tersebut. Urgensitas lainnya yang mendasari penelitian ini yaitu Prodi Pedidikan Jasmani UM Palopo secara akademik masuk pada tahapan penyelesaian study mahasiswa angkatan pertama dan disaat bersamaan terjadi situasi Pandemik Covid 19 sehingga mempersulit jalannya proses penelitian di lapangan, karenanya itu penelitian ini diharapkan menjadi acuan, pedoman dan tambahan literatur untuk mahasiswa dalam menjalankan penelitian secara daring.

Cabang olahraga sepakbola memiliki aspek-aspek penentu, sama halnya dengan cabang olahraga pada umumnya. Sepak bola adalah permainan yang kompleks sehingga membutuhkan latihan yang spesifik. Pemain sepakbola harus memiliki kebugaran aerobik yang baik, kecepatan, kekuatan, keterampilan bermain sepakbola, memahami taktik dan strategi dasar bermain sepakbola (Bryson et al., 2012). Prestasi maksimal dapat dicapai oleh seorang atlet yang benar-benar telah siap untuk berkompetisi dengan segala kemampuannya, kesiapan yang dimaksud adalah fisik dan psikologis atlet yang bersangkutan (Fallo \& Lauh, 2017). Untuk memiliki keterampilan bermain sepakbola atau terampil dalam melakukan teknik-teknik dasar dalam permainan sepakbola sangat dibutuhkan aspek fisiologis berupa komponen fisik yang prima (Maliki et al., 2017). Kondisi fisik yang baik merupakan salah satu cara pencapaian prestasi (Pratama \& Imanudin, 2019).Unsur-unsur kondisi fisik yang perlu dilatih dan ditingkatkan harus sesuai dengan cabang olahraga masing-masing atau sesuai dengan kebutuhannya dalam permainan maupun pertandingan (Efendi et al., 2018).

Kompleksnya unsur fisiologis yang dibutuhkan ketika seseorang bermain sepakbola mengisyaratkan seorang pemain sepakbola harus prima di semua komponen fisik yang dimilikinya. Teknik-teknik dasar seperti keterampilan passing, dribbling, shooting, jugling, dan heading memerlukan kesiapan komponen fisik seorang atlet. Pakar olahraga berpendapat bahwa untuk mempertahankan teknik-teknik dasar permaianan yang baik perlu ditunjang oleh kondisi fisik yang priama, apakah itu daya tahan, kekuatan, kelincahan, kecepatan, serta kordinasi (Hamdi et al., 2019). Bukan hanya kelincahan saja yang dibutuhkan oleh seorang pesepakbola dalam melakukan dribbling tapi kelentukan juga menjadi faktor penentu dalam menggiring bola (Maryono et al., 2017). Untuk melatih keterampilan shooting, baik pemain ataupun pelatih sepakbola haruslah mengetahui terlebih dahulu faktor-faktor yang menunjang dalam keterampilan shooting di lapangan yaitu: Kekuatan otot tungkai, power, koordinasi, body kinetic, body save, kelentukan, dan Flexibility adapun faktor psikologi yang mempengaruhi yaitu; Motivasi, percaya diri, konsentrasi, dan kecemasan, kerjasama (Habibie et al., 2019).

Kelincahan dan Kecepatan menjadi unsur fisik utama dalam melakukan teknik dribbling dalam melewati lawan, menjadi unsur pendukung dalam menentukan timing yang tepat pada saat passing, shooting, jugling, dan heading. Ada pengaruh signifikan antara latihan variasi kelincahan terhadap keterampilan dribbling sepakbola (Efendi et al., 2018). Seseorang yang memiliki kelincahan yang baik ia akan mampu melakukan perubahan arah, kecepatan dengan gerakan yang benar dan tepat saat sedang menggiring bola (Aditya et al., 2016). Koordinasi mata kaki merupakan bagian dari kemampuan biomotor yang dimiliki pemain, yang dapat berbengaruh terhadap hasil latihan (Syarif \& Suardi, 2019). Koordinasi dibutuhkan untuk semua aktivitas yang membutuhkan ketepatan terhadap suatu sasaran (Hartanto et al., 2017).

Keseimbangan merupakan komponen fisik yang dibutuhkan dihampir setiap keterampilan bermain sepakbola, keseimbangan dalam menggiring bola. Keseimbangan dalam melakukan shooting dan passing karena harus mensinergiskan antara posisi tubuh, posisi bola, dan kemana bola akan diarahkan. Keseimbangan kinerja otot postural dibutuhkan untuk menjaga kestabilan tubuh untuk menerima operan dan memasukkan bola ke gawang tim lain pada saat menyerang, mengubah arah gerakan dengan cepat ketika kembali ke posisi masing-masing serta menghindari gangguan pada punggung (Nasirudin et al., 2017).

Keterampilan bermain sepakbola tidak datang begitu saja, diperlukan proses panjang dalam bentuk latihan secara kontiniu sehingga sempurna pada saat berlatih dan bertanding. Kemauan untuk berlatih dengan gigih dan bertanding dengan semangat pantang menyerah dilapangan memerlukan aspek psikologis yang menyertai, Kemauan untuk berlatih dan bertanding diperoleh dari motivasi tinggi setiap pemain. Prestasi tidak akan datang sendirinya melainkan dengan perencanaan yang matang dan 
membutuhkan waktu yang lama (Hadi, 2019). Motivasi sebagai proses psikologis adalah refleksi kekuatan interaksi antara kognisi, pengalaman, dan kebutuhan (Fallo \& Lauh, 2017). Pencapaian prestasi membutuhkan suatu proses panjang dan membutuhkan motivasi yang biasanya didefinisikan sebagai proses yang menstimulasi perilaku atau menggerakkan kita untuk bertindak (Kurniawan et al., 2016).

Hasil penelitian terdahulu oleh Adil et al. (2018) menyimpulkan bahwa kecepatan, kelincahan, koordinasi mata-kaki, keseimbangan dan motivasi memiliki pengaruh terhadap keterampilan bermain sepakbola. Novellty penelitian yaitu menambahkan varibel kelentukan selain kecepatan, kelincahan, koordinasi mata-kaki, dan keseimbangan, serta lebih khusus pada motivasi berlatih, selanjutnya keseluruhan tes mengikuti ketentuan WFH (work from home) karena kondisi pandemik dan dipantau secara daring menggunakan aplikasi E-learning UM Palopo dan Google Form.

\section{METODE}

Jenis penelitian yang digunakan adalah analisis jalur (path analysis). Jenis penelitian yang digunakan adalah survei dengan teknik analisis jalur (path analysis). Variabel yang diujikan yaitu kelentukan (X1), kelincahan (X2), koordinasi mata-kaki (X3), kecepatan (X4), keseimbangan (X5) dan motivasi latihan (X6) terhadap keterampilan bermain sepakbola (Y).

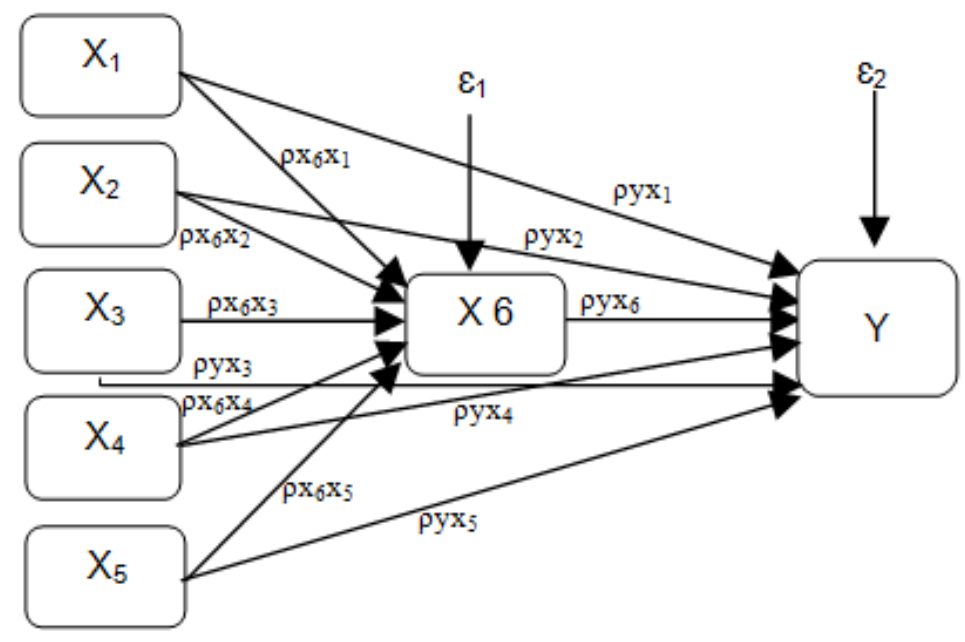

\section{Gambar 1. Model Teoritis}

Teknik sampling yang digunakan adalah sampel jenuh yaitu menggunakan seluruh populasi pemain sepakbola yang terdaftar pada UKM Olahraga Sepakbola UM Palopo untuk dijadikan sampel, berjumlah 57 orang. Waktu dan tempat penelitian mengikuti ketentuan WFH (work from home). Keseluruhan analisis data menggunakan uji regresi korelasional.

Data diperoleh melalui Instrumen tes sit-and-reach (kelentukan), tes shuttle run (kelincahan), tes koordinasi mata-kaki, tes sprinting speed 50 yards (kecepatan), modified bass test of dynamic balanced (keseimbangan) kuisioner motivasi latihan dan tes keterampilan sepak bola (tes passing, tes dribbling, tes shooting, tes jugling, dan tes heading) yang diakumulasi kemudian dijadikan nilai T-score. Waktu dan tempat penelitian mengikuti ketentuan WFH (work from home) dan dipantu menggunakan aplikasi E-learning

Data diperoleh melalui Instrumen tes sit-and-reach (kelentukan), tes shuttle run (kelincahan), tes koordinasi mata-kaki, tes sprinting speed 50 yards (kecepatan), modified bass test of dynamic balanced (keseimbangan). Motivasi latihan menggunakan kuisioner dengan skala Likert serta item pertanyaan yang bersifat positif dan negativ, jawaban dengan kategori skala yang bervariasi menggunakan skala Likert. Proses penyusunan angket dimulai dengan membuat konsep yang sesuai dengan penelitian.

Angket motivasi terdiri dari dua jenis yaitu pernyataan positif dan negatif. Maka penulis menggunakan skala likert. Item positif dan item negatif menggunakan skor nilai 1-5. Tahap akhir penyusunan angket dan sebelum dilakukan penelitian maka terlebih dahulu dilaku-kan pengujian untuk mengetahui apakah angket tersebut valid atau tidak dengan menggunakan pengaju-an validitas dan realibilitas untuk item-item soalnya. 
Jurnal Keolahragaan 8 (2), 2020 - 129

Firmansyah Dahlan, Rahmad Hidayat, Syahruddin Syahruddin

Tabel 1. Kisi-Kisi Angket Motivasi

\begin{tabular}{|c|c|c|c|c|c|}
\hline \multirow{2}{*}{ No. } & \multirow{2}{*}{ Aspek } & \multirow{2}{*}{ Indikator } & \multicolumn{2}{|c|}{ No. item } & \multirow{2}{*}{ Jumlah } \\
\hline & & & Positif & Negatif & \\
\hline \multirow[t]{4}{*}{1.} & Atlet itu sendiri & Kepuasan dalam diri atlet & 1,2 & 3 & 3 \\
\hline & & $\begin{array}{l}\text { Tekun, kerja keras, teratur dan disiplin dalam } \\
\text { menjalani latihan olahraga. }\end{array}$ & $4,5,6,7$ & $\begin{array}{l}8,9 \\
10,11\end{array}$ & 8 \\
\hline & & $\begin{array}{l}\text { Tidak bergantung pada orang lain dalam menjalani } \\
\text { latihan olahraga }\end{array}$ & 12 & 13 & 2 \\
\hline & & Memiliki kepribadian yang positif dan matang & 14,15 & & 2 \\
\hline \multirow[t]{2}{*}{2.} & $\begin{array}{l}\text { Hasil } \\
\text { Penampilan }\end{array}$ & $\begin{array}{l}\text { Mengikuti pertandingan olahraga karena adanya } \\
\text { imbalan. }\end{array}$ & $16,17,18$ & $\begin{array}{l}19,20, \\
21\end{array}$ & 6 \\
\hline & & $\begin{array}{l}\text { Mengikuti pertandingan olahraga karena ingin } \\
\text { mendapatkan pujian dari orang lain. }\end{array}$ & 22 & 23 & 2 \\
\hline \multirow[t]{2}{*}{3.} & $\begin{array}{l}\text { Suasana } \\
\text { Pertandingan }\end{array}$ & $\begin{array}{l}\text { Adanya dukungan dari penonton pada saat } \\
\text { pertandingan }\end{array}$ & 24 & 25 & 2 \\
\hline & & Adanya dukungan dari keluarga & 26 & 27 & 2 \\
\hline \multirow[t]{3}{*}{4.} & Tugas atau & Kesadaran atlet mendalami olahraga. & 28 & 29 & 2 \\
\hline & penampilan & $\begin{array}{l}\text { Memiliki sikap sportif dalam pertandingan } \\
\text { olahraga. }\end{array}$ & $\begin{array}{l}30,31,32, \\
33\end{array}$ & 34,35 & 6 \\
\hline & & Jumlah & 19 & 14 & 35 \\
\hline
\end{tabular}

Tabel 2. Skor Alternatif Jawaban

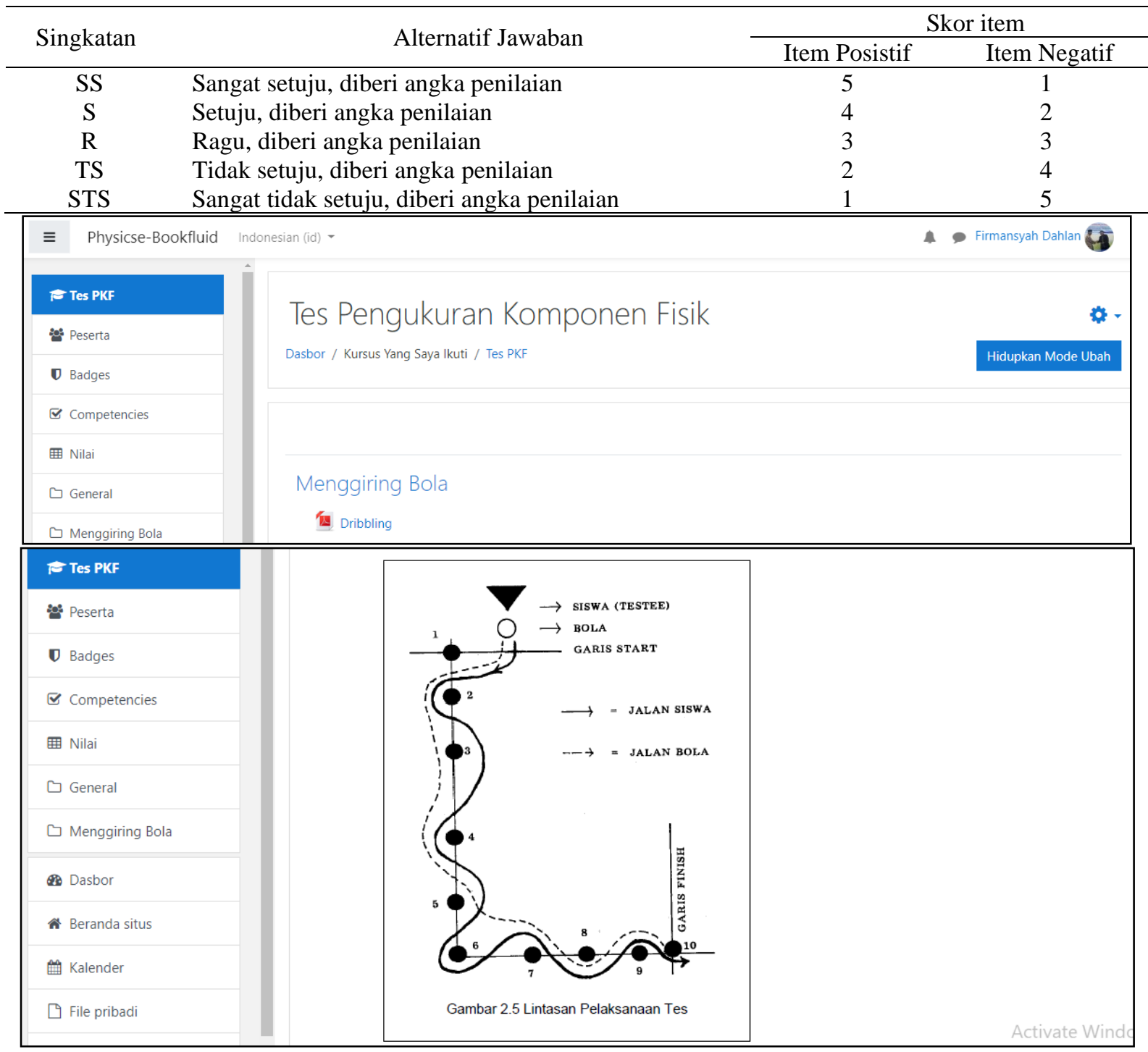

Gambar 2. Penumpulan Data Menggunakan Aplikasi E-learning UM Palopo

Copyright $\odot$ 2020, Jurnal Keolahragaan, ISSN 2339-0662 (print), ISSN 2461-0259 (online) 


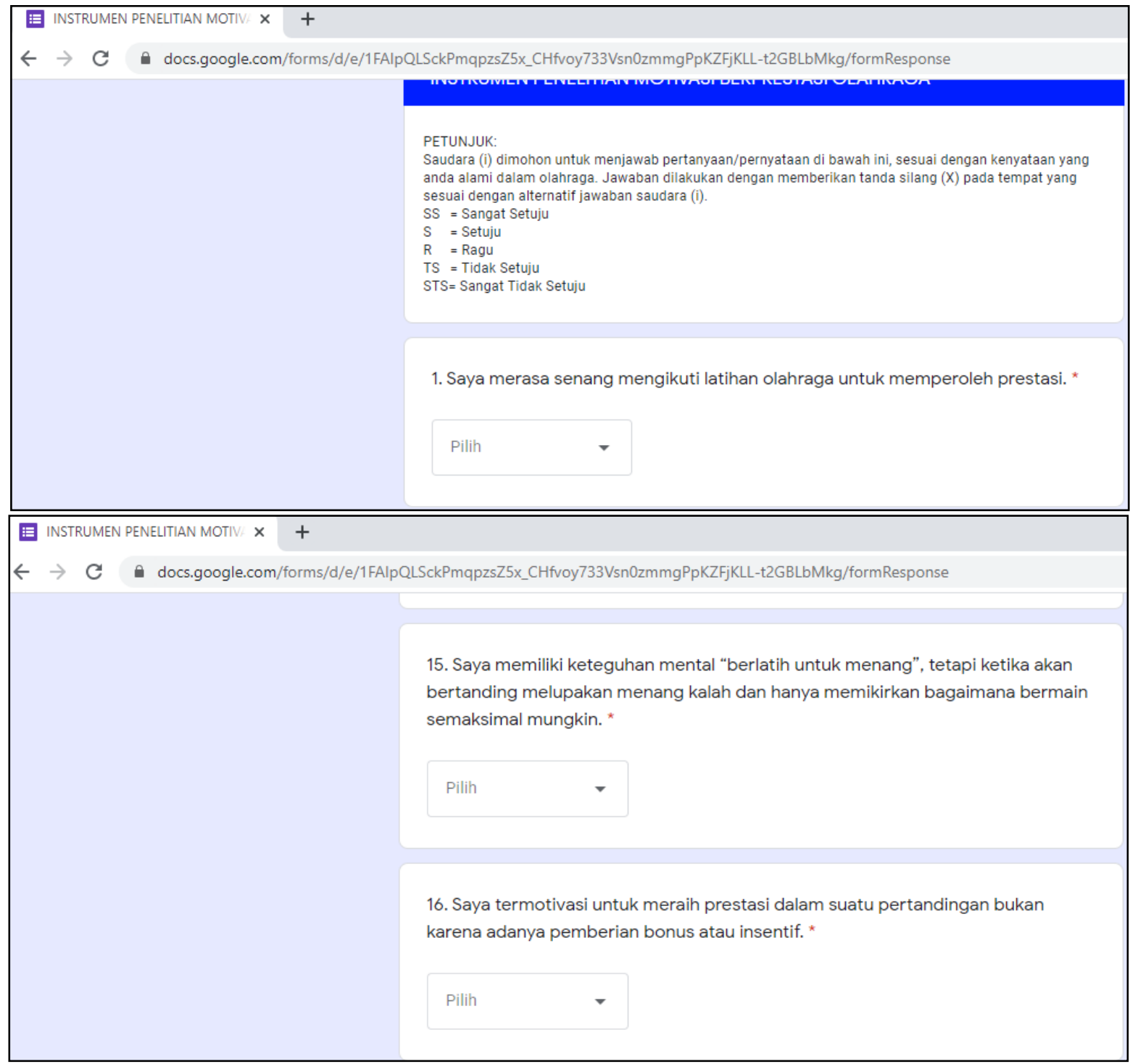

Gambar 3. Kuisioner motivasi latihan menggunakan aplikasi Google form

Konsep keterampilan bermain sepakbola tidak dapat diartikan dengan arti sempit karena dalam keterampilan bermain sepakbola terdapat keterampilan menyerang, keterampilan bertahan, keterampilan bermain sepakbola menggunakan bola dan tanpa bola (Yang, 2014). Untuk meningkatkan keterampilan teknik khusus bermain sepakbola dilatih dalam sesi khusus dan tingkat kesulitan yang lebih tinggi, lebih lanjut klasifikasi keterampilan bermain sepakbola yaitu Technique in basic, Technique in intermediate, Technique in the advanced (FIFA, 2016). Berdasarkan hal tersebut maka ruang lingkup keterampilan bermain sepakbola yang dimaksud dalam penelitian ini mengarah pada basic skill, basic technique, fundamental technique, atau fundamental skill sehingga instrumen tes yang akan digunakan yaitu tes teknik dasar (passing, dribbling, shooting, juggling, dan heading). Penekanan ini menjadi sangat penting mengingat cakupan keterampilan bermain sepakbola sangatlah luas dan identik dengan pengem-bangan teknik dasar dalam bentuk penambahan variasi maupun peningkatan kehalusan gerak yang lebih maksimal atau yang disebut special technique ataupun professional skill.

Argumentasi lainnya yang menjadi rujukan. Pengembangan aplikasi tes keterampilan sepakbola berbasi web dimana aplikasi tes terdiri dari tujuh item tes keterampilan sepakbola yaitu: tes dribbling, pass-ing-control, shooting, passing lambung, juggling, heading (Supriyono, 2018). Konteks lain yang menda-sari adalah adanya ketentuan WFH (work from home) sehingga instrument tes dipersiapkan oleh tester sehingga tes teknik dasar dianggap jauh lebih memudahkan.

Proses pengambilan data menggunakan aplikasi E-learning UM Palopo (Gambar 2) dan aplikasi Google form (Gambar 3). Pertama, sampel mendownload panduan tes kelentukan (X1), kelincahan (X2), koordinasi mata-kaki (X3), kecepatan (X4), keseimbangan (X5) dan keterampilan bermain sepak- 
bola (Y) dan menyusun keperluan serta perangkat instrument tes secara mandiri. Kedua, sampel selanjutnya mengapload video, foto, dan data hasil tes kedalam aplikasi E-learning UM Palopo. Ketiga, link kuisioner motivasi latihan (X6) dibagikan keseluruh sampel dan diisi secara daring menggunakan aplikasi Google form (https://bit.ly/371wxzE).

\section{HASIL DAN PEMBAHASAN}

Hasil analisis deskriptif untuk variabel yang diujikan yaitu kelentukan (X1), kelincahan (X2), koordinasi mata-kaki (X3), kecepatan (X4), keseimbangan (X5) dan motivasi latihan (X6) terhadap keterampilan bermain sepakbola (Y).

Tabel 1. Style dan Fungsinya

\begin{tabular}{cccccc}
\hline Variabel & N & Min & Max & Mean & Std. D \\
\hline X1 & 57 & 2 & 30 & 17,15 & 7,41 \\
X2 & 57 & 19,82 & 35,35 & 24,34 & 2,89 \\
X3 & 57 & 0 & 17 & 8,03 & 3,77 \\
X4 & 57 & 7,48 & 9,66 & 8,67 & 0,54 \\
X5 & 57 & 30 & 100 & 67,84 & 17,75 \\
X6 & 57 & 129 & 171 & 149,15 & 10,883 \\
Y & 57 & 34 & 72 & 53,14 & 9,159 \\
\hline
\end{tabular}

Kelentukan (X1) nilai rata-rata 17,15, standar deviasi sebesar 7,413, nilai minimum 2, maximum 30. Kelincahan (X2) nilai rata-rata 24,34, standar deviasi sebesar 2,892, nilai minimum 19,82, maximum 35,35. Koordinasi mata-kaki (X3) nilai rata-rata 8,03, standar deviasi sebesar 3,774, nilai minimum 0 , maximum 17. Kecepatan (X4) nilai rata-rata 8,67, standar deviasi sebesar 0,542, nilai minimum 7,48, maximum 9,66. Keseimbangan (X5) nilai rata-rata 67,84, standar deviasi sebesar 17,753, nilai minimum 30, maximum 100. Motivasi latihan (X6) nilai rata-rata 149,15, standar deviasi sebesar 10,883, nilai mini-mum 129, maximum 171. Keterampilan bermain sepakbola (Y) nilai rata-rata 53,14, standar deviasi sebesar 9,159, nilai minimum 34, maximum 72 .

\section{Uji Model}

Substruktur 1

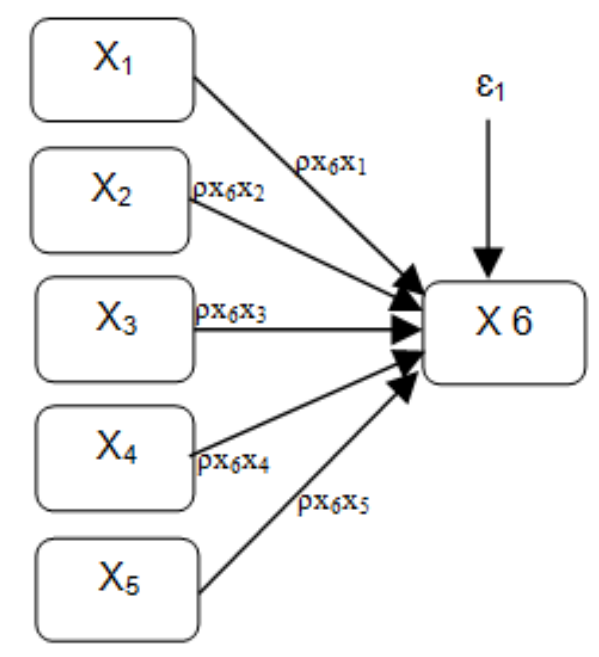

Gambar 2. Substruktur 1

Tabel 3. Koefisien Determinasi Substruktur 1

\begin{tabular}{ccccc}
\hline Model & $\mathrm{R}$ & Koefisien Determinasi & Adjusted Koefisien Determinasi & Std. Eror \\
\hline 1 & $0,879^{\mathrm{a}}$ & 0,773 & 0,751 & 5,427 \\
\hline
\end{tabular}

Tabel 3 nilai $R$-Square menunjukkan angka $0,813^{\text {a }}$, secara simultan variabel kelentukan (X1), kelincahan (X2), koordinasi mata-kaki (X3), kecepatan (X4), dan keseimbangan(X5) memiliki kontribusi sebesar 77,3\% dalam menjelaskan perubahan yang terjadi pada variabel motivasi (X6), sedangkan 
Jurnal Keolahragaan 8 (2), 2020 - 132

Firmansyah Dahlan, Rahmad Hidayat, Syahruddin Syahruddin

sisanya 23,7 \% ditentukan oleh variabel lain di luar model. Untuk Anova (uji F) secara simultan variabelvariabel bebas memiliki pengaruh yang signifikan terhadap variabel motivasi latihan, sig. $0,000^{\mathrm{b}}<$ Alpha $5 \%$.

Tabel 4. Analisis Multivariat Regresi Model 1 Sub Struktur I

\begin{tabular}{ccccc}
\hline Model & Variabel & KoefisienKorelasi & $\mathrm{T}$ & $P$ \\
\hline 1 & X1 & 0,204 & 2,075 & $0,043<0,05$ \\
X2 & 0,261 & 2,972 & $0,005<0,05$ \\
X3 & 0,281 & 2,756 & $0,008<0,05$ \\
& X4 & 0,207 & 2,417 & $0,019<0,05$ \\
& X5 & 0,206 & 2,387 & $0,021<0,05$ \\
& & & 0,000 \\
\hline
\end{tabular}

Selain itu, pada Tabel 4 dengan melihat nilai koefisien terlihat bahwa variabel kelentukan (X1) 0,204 atau sebesar 20\%, serta nilai T sebesar 2,075, adapun secara statistik memliki pengaruh yang signifikan terhadap variabel motivasi latihan (X6) yang ditunjukkan oleh nilai sig. lebih kecil dari Alpha $5 \%$ yaitu 0,043 .

Terdapat pengaruh kelentukan terhadap motivasi latihan sebesar 20,4\%. Hal tersebut menunjukkan bahwa hasil penelitian ini sejalan dengan hasil penelitian sebelumnya. Terdapat pengaruh langsung kelentukan terhadap motivasi pada siswa SMPN 1 Bajeng Kabupaten Gowa (Hiskyia, 2017). Kelentukan yang baik akan memberi keluasan bergerak pada seorang atlet, memicu keinginan atlet untuk terus bekerja dengan maksimal dan secara langsung memotivasi atlet dalam berlatih. Kelentukan merupakan salah satu komponen fisik yang dimiliki setiap orang untuk mewujudkan gerakan yang luwes, lancar dan tidak kaku, maka unsur kondisi fisik ini dikembangkan menjadi kemampuan gerak yang mendukung penguasaan kemampuan keterampilan olahraga (Ambarwati et al., 2017). Kata motif disamakan artinya dengan kata-kata motive, motif, dorongan, alasan, dan driving force. Motif merupakan daya pendorong atau suatu tenaga di dalam diri manusia yang menyebabkan menusia bertindak dengan cara tertentu (Prabowo, 2016). Berdasarkan penjabaran tersebut maka dapat disimpulkan bahwa kelentukan membantu penguasaan kemampuan keterampilan olahraga sehingga memiliki hubungan dengan motivasi seseorang karena adanya keluasan gerak yang dimiliki.

Nilai koefisien terlihat bahwa variabelkelincahan (X2) 0,261 atau sebesar 26\%, serta nilai T sebesar 2,972, adapun secara statistik memliki pengaruh yang signifikan terhadap variabel motivasi latihan (X6) yang ditunjukkan oleh nilai sig. lebih kecil dari Alpha 5\% yaitu 0,005. Terdapat pengaruh kelincahan terhadap motivasi latihan sebesar $26,1 \%$. Hal tersebut menunjukkan bahwa hasil penelitian ini sejalan dengan hasil penelitian sebelumnya. Kelincahan berpengaruh langsung dan tidak langsung terhadap motivasi berolahraga Siswa SMA Negeri 1 Panggarangan Kabupaten Lebak (Ridwan, 2016). Kelincahan adalah kemampuan menyesuaikan posisi tubuh terhadap situasi kerja yang dihadapi sehingga kemampuan menyesuaikan diri dengan situasi kerja tersebut akan berpengaruh terhadap motivasi latihan.

Nilai koefisien terlihat bahwa variabelkoordinasi mata-kaki (X3) 0,281, atau sebesar 28\%, serta nilai $\mathrm{T}$ sebesar 2,752, adapun secara statistik memliki pengaruh yang signifikan terhadap variabel motivasi latihan (X6) yang ditunjukkan oleh nilai sig. lebih kecil dari Alpha 5\% yaitu 0,008. Terdapat pengaruh koordinasi mata-kaki terhadap motivasi latihan sebesar $28,1 \%$ Hal tersebut menunjukkan bahwa hasil penelitian ini sejalan dengan hasil penelitian sebelumnya. Ada pengaruh koordinasi mata kaki terhadap motivasi pemain Ponrang FC Kabupaten Luwu (Paisal, 2018). Koordinasi mata-kaki merupakan kemampuan seseorang dalam mengotrol fungsi-fungsi anggota tubuhnya sehigga memberi efek kemudahan dalam melakukan kerja-kerja maksimal dan hal ini pula yang memberikan motivasi atlet untuk berlatih.

Nilai koefisien terlihat bahwa variabelkecepatan (X4) 0,207, atau sebesar 20\%, serta nilai T sebesar 2,415, adapun secara statistik memliki pengaruh yang signifikan terhadap variabel motivasi latihan (X6) yang ditunjukkan oleh nilai sig. lebih kecil dari Alpha 5\% yaitu 0,019. Terdapat pengaruh kecepatan terhadap motivasi latihan sebesar $20,6 \%$. Hal tersebut menunjukkan bahwa hasil penelitian ini sejalan dengan hasil penelitian sebelumnya. Ada pengaruh kecepatan terhadap motivasi pemain Ponrang FC Kabupaten Luwu (Paisal, 2018). Kecepatan muncul dari dorongan keingingan atlet untuk melakukan gerakan yang cepat dan maksimal, hal tersebut tentunya dihasilkan oleh motivasi yang baik pula, sehingga kecepatan berpengaruh terhadap motivasi latihan. Melalui kecepatan yang dimiliki akan memudah- 
kan atlet untuk menjalankan dan menyelesaikan tugas-tugasnya, hal itu tentunya akan memiliki efek pada motivasi atlet untuk berlatih.

Nilai koefisien terlihat bahwa variabelkeseimbangan (X5)0,206, atau sebesar 20\%, serta nilai $\mathrm{T}$ sebesar 2,387, adapun secara statistik memliki pengaruh yang signifikan terhadap variabel motivasi latihan (X6) yang ditunjukkan oleh nilai sig. lebih kecil dari Alpha 5\% yaitu 0,021. Terdapat pengaruh keseimbangan terhadap motivasi latihan sebesar $20,7 \%$. Hal tersebut menunjukkan bahwa hasil penelitian ini sejalan dengan hasil penelitian sebelumnya. Keseimbangan berpengaruh langsung terhadap motivasi berolahraga Siswa SMA Negeri I Panggarangan (Ridwan, 2016). Keseimbangan adalah kemampuan dalam mengontrol fungsi gerak dan posisi tubuh. Melalui kemampuan dalam mengontrol fungsi gerak dan posisi tubuh tersebut akan berpengaruh terhadap motivasi berlatih.

Untuk pengaruh variabel lain diluar model $\left(\varepsilon_{1}\right)$ dapat ditentukan rumus:

$\varepsilon_{1}=\sqrt{1-R^{2}}$

Sehingga persamaan jalurnya adalah sebagai berikut:

$\mathrm{X}_{6}=\rho \mathrm{x}_{6} \mathrm{X}_{1}+\rho \mathrm{x}_{6} \mathrm{X}_{2}+\rho \mathrm{x}_{6} \mathrm{X}_{3}+\rho \mathrm{x}_{6} \mathrm{X}_{4}+\rho \mathrm{x}_{6} \mathrm{X}_{5}+\varepsilon_{1}$

$\mathrm{X} 6=0,204 \mathrm{X} 1+0,261 \mathrm{X} 2+0,281 \mathrm{X} 3+0,206 \mathrm{X} 4+0,207 \mathrm{X} 5+0,4764$

Substruktur 2

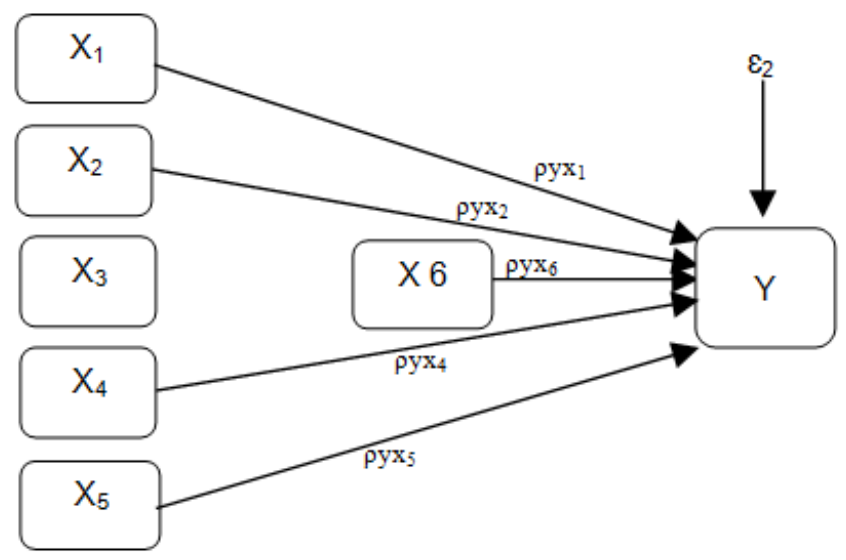

Gambar 3. Substruktur 2

Tabel 5. Koefisien Determinasi Substruktur 2

\begin{tabular}{ccccc}
\hline Model & $\mathrm{R}$ & Koefisien Determinasi & Adjusted Koefisien Determinasi & Std. Eror \\
\hline 2 & $0,906^{\mathrm{a}}$ & 0,820 & 0,798 & 4,112 \\
\hline
\end{tabular}

Tabel 5 nilai $R$-Square menunjukkan angka $0,906^{\mathrm{a}}$, secara simultan variabel kelentukan (X1), kelincahan (X2), koordinasi mata-kaki (X3), kecepatan (X4), keseimbangan (X5), dan motivasi (X6) memiliki kontribusi sebesar $82,3 \%$ dalam menjelaskan perubahan yang terjadi pada variabel keterampilan bermain sepakbola (Y), sedangkan sisanya 17,7\% ditentukan oleh variabel lain di luar model. Untuk Anova (uji F) secara simultan variabel-variabel bebas memiliki pengaruh yang signifikan terhadap variabel keterampilan bermain sepakbola, sig. $0,000^{\mathrm{b}}<$ Alpha $5 \%$.

Tabel 6. Analisis Multivariat Regresi Model 2 Sub Struktur 2

\begin{tabular}{ccccc}
\hline Model & Variabel & Koefisien Korelasi & $\mathrm{T}$ & $P$ \\
\hline 2 & X1 & 0,237 & 2,572 & $0,013<0,05$ \\
X2 & 0,180 & 2,100 & $0,041<0,05$ \\
X3 & 0,278 & 2,820 & $0,007<0,05$ \\
X4 & 0,332 & 4,083 & $0,000<0,05$ \\
X5 & 0,223 & 2,729 & $0,009<0,05$ \\
X6 & 0,308 & 2,443 & $0,018<0,05$ \\
& & & 0,009 \\
\hline
\end{tabular}

Selain itu, pada Tabel 6 dengan melihat nilai koefisien terlihat bahwa variabel kelentukan (X1) 0,237 , atau sebesar $23 \%$, serta nilai T sebesar 2,572 , secara statistik memliki pengaruh yang signifikan 
terhadap variabel keterampilan bermain sepakbola (Y) yang ditunjukkan oleh nilai sig. lebih kecil dari Alpha 5\% yaitu 0,013. Terdapat pengaruh kelentukan terhadap keterampilan bermain sepakbola sebesar 23,7\%, Hal tersebut menunjukkan bahwa hasil penelitian ini sejalan dengan hasil penelitian sebelumnya. Dapat disimpulkan bahwa latihan yang dilakukan kelompok latihan kelincahan dan kelentukan dapat meningkatkan keterampilan dribbling bola, karena latihan tersebut mengandung unsur kelincahan, dan koordinasi, dan kemampuan meregang selain itu latihan tersebut memberikan pengaruh yang lebih baik daripada latihan konvensional dalam upaya peningkatan keterampilan dribbling bola (Utama et al., 2015). Kualitas kelentukan yang dimiliki setiap orang berbeda-beda, kelentukan yang baik memungkinkan otot atau sekelompok otot untuk berkontraksi dengan melibatkan sistem lokomotor tubuh untuk berkerja sama dalam melakukan aktifitas gerak (Ambarwati et al., 2017). Keseluruhan pakar tentunya sepakat dengan pengaruh kelentukan akan performa atlet, kelentukan maksimal mengurangi energy yang harus dikeluarkan pada saat bergeran dan kelentukan yang baik akan mengurangi resiko cedera.

Nilai koefisien terlihat bahwa variabelkelincahan (X2), 0,180 atau sebesar 18\%, serta nilai T sebesar 2,100, secara statistik memliki pengaruh yang signifikan terhadap variabel keterampilan bermain sepakbola (Y) yang ditunjukkan oleh nilai sig. lebih kecil dari Alpha 5\% yaitu 0,041. Terdapat pengaruh kelincahan terhadap keterampilan bermain sepakbola sebesar 18\%. Hal tersebut menunjukkan bahwa hasil penelitian ini sejalan dengan hasil penelitian sebelumnya. Berdasarkan hasil analisis diperoleh kebutuhan fisik yang berbeda- beda, kelincahan 14,00\% (Hidayat et al., 2019). Kelincahan akan mampu menjadi faktor penentu dilapangan, dalam penjagaan yang ketat oleh pemain lawan tentunya dibutuhkan pemain yang mampu keluar dari situasi sulit sehingga pemain yang memiliki kelincahan akan dengan mudah membuat peluang.

Nilai koefisien terlihat bahwa variabelkoordinasi mata-kaki (X3) 0,278 atau sebesar 27\%, serta nilai $\mathrm{T}$ sebesar 2,820, secara statistik memliki pengaruh yang signifikan terhadap variabel keterampilan bermain sepakbola (Y) yang ditunjukkan oleh nilai sig. lebih kecil dari Alpha 5\% yaitu 0,007. Terdapat pengaruh koordinasi mata - kaki terhadap keterampilan bermain sepakbola sebesar 27,8\%. Hal tersebut menunjukkan bahwa hasil penelitian ini sejalan dengan hasil penelitian sebelumnya. Semakin baik koordinasi mata-kaki dan kelincahan para siswa, maka keterampilan menggiring bola akan semakin baik sehingga prestasi sepakbola (Sakti, 2017). Keterampilan menendang bola erat hubungannya dengan Kekuatan Otot tungkai, Koordinasi mata-kaki, dan kepercayaan diri (Rahmansyah et al., 2018). Kesuksesan cabang olahraga sepakbola ditentukan oleh kemampuan menempatkan posisi dan mengarahkan bola ketempat yang menguntungkan, kedua hal tersebut membutuhkan kemampuan koordinasi matakaki yang baik.

Nilai koefisien terlihat bahwa variabel kecepatan (X4) 0,332 atau sebesar 33\%, serta nilai T 4,083, secara statistik memliki pengaruh yang signifikan terhadap variabel keterampilan bermain sepakbola (Y) yang ditunjukkan oleh nilai sig. lebih kecil dari Alpha 5\% yaitu 0,000. Terdapat pengaruh kecepatan terhadap keterampilan bermain sepakbola sebesar 33,2\%. Hal tersebut menunjukkan bahwa hasil penelitian ini sejalan dengan hasil penelitian sebelumnya, Berdasarkan hasil analisis diperoleh kebutuhan fisik yang berbeda-beda, kecepatan 14,00\% (Hidayat et al., 2019).Mengambil keputusan dengan cepat dan tepat serta bergerak dengan cepat dan tepat adalah hal yang sangat membantu dalam memenangkan pertandingan

Nilai koefisien terlihat bahwa variabel Keseimbangan (X5) 0,223 atau sebesar 22\%, serta nilai T 2,729 , secara statistik memliki pengaruh yang signifikan terhadap variabel keterampilan bermain sepakbola (Y) yang ditunjukkan oleh nilai sig. lebih kecil dari Alpha 5\% yaitu 0,009. Terdapat pengaruh keseimbangan terhadap keterampilan bermain sepakbola sebesar $22 \%$. Hal tersebut menunjukkan bahwa hasil penelitian ini sejalan dengan hasil penelitian sebelumnya. Terdapat hubungan keseimbangan dengan hasil dribbling menggunakan kaki bagian luar (Hartati \& Ryansyah, 2019). Keseimbangan berpengaruh terhadap ketepatan shooting (Rosita et al., 2019). Dalam permainan sepakbola seorang pemain tidak akan mudah menguasai bola dalam waktu yang lama, akan ada halangan dan pressing ketat dari lawan, dalam keadaan tersebut keseimbangan adalah faktor yang sangat menentukan.

Nilai koefisien terlihat bahwa variabel motivasi (X6) 0,308 atau ssebesar 30\%, serta nilai T 2,443, secara statistik memliki pengaruh yang signifikan terhadap variabel keterampilan bermain sepakbola (Y) yang ditunjukkan oleh nilai sig. lebih kecil dari Alpha 5\% yaitu 0,018. Terdapat pengaruh motivasi terhadap keterampilan bermain sepakbola sebesar 30\% Hal tersebut menunjukkan bahwa hasil penelitian ini sejalan dengan hasil penelitian sebelumnya, ada kontribusi antara motivasi terhadap prestasi atlet. Ada kontribusi antara motivasi dan kerjasama terhadap prestasi atlet (Apriansyah et al., 2017). Ada 
kontribusi antara motivasi dan kepercayaan diri terhadap prestasi atlet. Terdapat pengaruh positif yang signifikan antara motivasi berprestasi dengan keterampilan teknik dasar sepakbola (Suprayitno \& Damanik, 2016). Berlatih adalah kunci dari semua cabang olahraga prestasi, pemenang tentunya adalah atlet yang memiliki motivasi berlatih yang tinggi.

Untuk pengaruh variabel lain diluar model dapat ditentukan rumus:

$\varepsilon_{1}=\sqrt{1-R^{2}}$

Sehingga persamaan jalurnya adalah sebagai berikut:

$\mathrm{Y}=\rho \mathrm{yx}_{1}+\rho \mathrm{yx}_{2}+\rho \mathrm{yx}_{3}+\rho \mathrm{yx}_{4}+\rho \mathrm{yx}_{5}+\rho \mathrm{yx}_{6}+\varepsilon_{2}$

$Y=0,237 X_{1}+0,180 X_{2}+0,278 X_{3}+0,332 X_{4}+0,223 X_{5}+0,308 X_{6}+0,2121$

Hasil penggabungan model Substruktur 1 dan Substruktur 2 diperoleh struktur seperti Gambar 4.

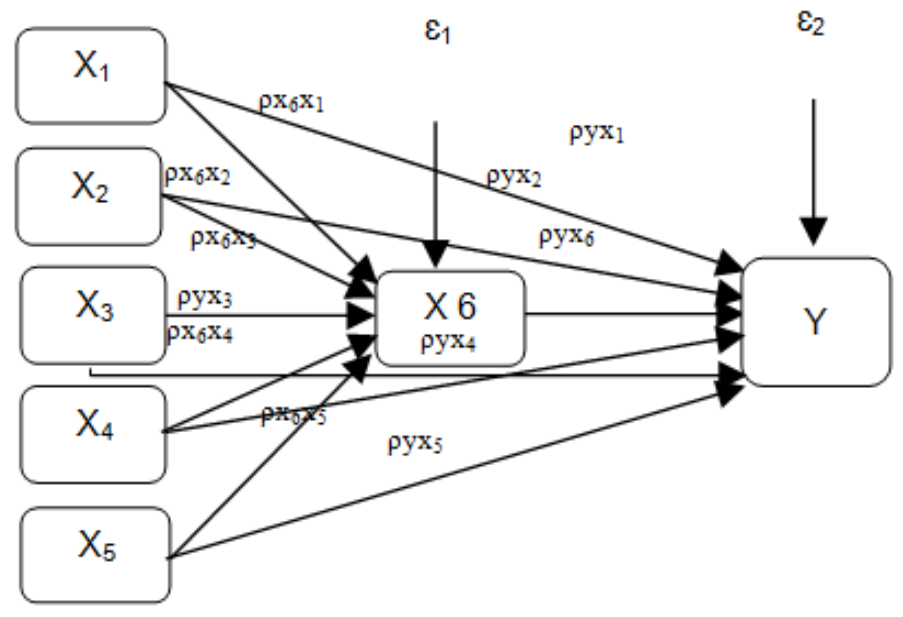

Gambar 4. Model hasil pengujian substruktur 1 dan substruktur 2

Dari Gambar 4 maka dapat dibuat persamaan struktur sebagai berikut:

$\mathrm{X} 6=\rho \mathrm{x}_{6} \mathrm{x}_{1}+\rho \mathrm{x}_{6} \mathrm{x}_{2}+\rho \mathrm{x}_{6} \mathrm{x}_{3}+\rho \mathrm{x}_{6} \mathrm{x}_{4}+\rho \mathrm{x}_{6} \mathrm{x}_{5}+\varepsilon_{1}$

$\mathrm{X} 6=0,204 \mathrm{X} 1+0,261 \mathrm{X} 2+0,281 \mathrm{X} 3+0,206 \mathrm{X} 4+0,207 \mathrm{X} 5+0,4764$

$\mathrm{Y}=\rho \mathrm{yx}_{1}+\rho \mathrm{yx}_{2}+\rho \mathrm{yx}_{3}+\rho \mathrm{yx}_{4}+\rho \mathrm{yx}_{5}+\rho \mathrm{yx}_{6}+\varepsilon_{2}$

$Y=0,237 X_{1}+0,180 X_{2}+0,278 X_{3}+0,332 X_{4}+0,223 X_{5}+0,308 X_{6}+0,2121$

Tabel 7. Hasil Pengujian Hipotesis

\begin{tabular}{ccc}
\hline Hipotessis & Koefisien $\beta$ & A \\
\hline 1 & 0,204 & 0,043 \\
2 & 0,261 & 0,005 \\
3 & 0,281 & 0,008 \\
4 & 0,206 & 0,019 \\
5 & 0,207 & 0,021 \\
6 & 0,237 & 0,013 \\
7 & 0,180 & 0,041 \\
8 & 0,278 & 0,007 \\
9 & 0,332 & 0,009 \\
10 & 0,223 & 0,000 \\
11 & 0,308 & 0,018 \\
12 & 0,062 & 0,000 \\
13 & 0,080 & 0,000 \\
14 & 0,086 & 0,000 \\
15 & 0,063 & 0,000 \\
\hline
\end{tabular}

Berdasarkan Tabel 7, untuk Hipotesis 12, pengujian Nilai koefisien terlihat bahwa variabel kelentukan (X1) 0,062 atau sebesar 6\%, secara statistik memliki pengaruh yang signifikan terhadap variabel keterampilan bermain sepakbola $(\mathrm{Y})$ melalui motivasi $(\mathrm{X})$ yang ditunjukkan oleh nilai sig. lebih kecil 
dari Alpha 5\% yaitu 0,000. Terdapat pengaruh kelentukan terhadap keterampilan bermain sepakbola melalui motivasi berlatih sebesar $6 \%$. Kelentukan faktor penting dalam olahraga prestasi dan sepakbola, komponen tersebut diasah dan dikembangakan melalui proses berlatih yang berdampak pada peningkatan keterampilan bermain sepakbola dan performa di lapangan. Kelentukan berguna untuk keseimbangan dalam melakukan dribbling (Utama et al., 2015). Motivasi merupakan keseluruhan daya penggerak dalam diri siswa yang menimbulkan kegiatan belajar yang menjamin kelangsungan dari kegiatan belajar dan memberikan arah kegiatan belajar sehingga tujuan yang dikehendaki dapat terwujud (Syahruddin et al., 2019). Kondisi fisik yang prima, perlu ditunjang dengan penggunaan teknik dan taktik yang memadai, serta afirmasi mental merupakan posisi akhir dari piramida prestasi olahraga (Blegur \& Mae, 2018).

Berdasarkan Tabel 7, untuk Hipotesis 13, pengujian Nilai koefisien terlihat bahwa variabel kelincahan (X2) 0,080 atau sebesar 8\%, secara statistik memliki pengaruh yang signifikan terhadap variabel keterampilan bermain sepakbola (Y) melalui motivasi (X) yang ditunjukkan oleh nilai sig. lebih kecil dari Alpha 5\% yaitu 0,000. Terdapat pengaruh kelincahan terhadap keterampilan bermain sepakbola melalui motivasi berlatih sebesar $8 \%$. Kelincahan gerakan sangat identik dengan permainan sepakbola, kelincahan yang dikembangkan dari proses berlatih yang baik dan motivasi tinggi akan menentukan hasil akhir dilapangan. Peningkatan keterampilan dribbling ini dikarenakan dalam latihan kelincahan dan kelentukan terdapat unsur-unsur penunjang dalam keterampilan dribbling yaitu kelincahan yang meliputi kecepatan dan koordinasi (Utama et al., 2015). Hal utama yang harus dilakukan oleh pemain sebakbola agar memiliki keterampilan dribbling yang baik adalah dengan meningkatkan kelincahan (Efendi et al., 2018).

Berdasarkan Tabel 7, untuk Hipotesis 14, pengujian Nilai koefisien terlihat bahwa variabel koordinasi mata-kaki (X3) 0,086 atau sebesar 8\%, secara statistik memliki pengaruh yang signifikan terhadap variabel keterampilan bermain sepakbola $(\mathrm{Y})$ melalui motivasi $(\mathrm{X})$ yang ditunjukkan oleh nilai sig. lebih kecil dari Alpha 5\% yaitu 0,000. Terdapat pengaruh koordinasi mata-kaki terhadap keterampilan bermain sepakbola melalui motivasi berlatih sebesar $8 \%$. Komponen fisik yang dikembangkan melalui proses berlatih yang baik dan motivasi tinggi akan berdampak pada performa dilapangan. Para pelatih disarankan untuk menerapkan dan memperhatikan tentang koordinasi mata-kaki dan kelincahan dalam menjalankan program latihan, disamping faktor-faktor lain yang ikut menunjang keberhasilan kemampuan menggiring bola (Sakti, 2017). Disimpulkan bahwa terdapat kontribusi kekuatan otot tungkai dan koordinasi mata dan kaki terhadap akurasi tendangan ke gawang (shooting) (Zainur \& Sulastio, 2019).

Berdasarkan Tabel 7, untuk Hipotesis 15, pengujian Nilai koefisien terlihat bahwa variabel kecepatan (X4) 0,063 atau sebesar 6\%, secara statistik memliki pengaruh yang signifikan terhadap variabel keterampilan bermain sepakbola (Y) melalui motivasi (X) yang ditunjukkan oleh nilai sig. lebih kecil dari Alpha 5\% yaitu 0,000. Terdapat pengaruh kecepatan terhadap keterampilan bermain sepakbola melalui motivasi berlatih sebesar $6 \%$. Kecepatan bergerak menanggapi rangsangan dan kecepatan kerja secara tepat, tentunya lahir dari faktor motivasi yang tinggi dalam latihan. Akan sulit menemukan atlet yang berkeinginan bergerak cepat setelah rangsangan maupun bekerja secara secap dan tepat tampa didasari oleh motivasi. Motivasi merupakan salah satu komponen faktor psikologis atlet yang sangat diperlukan pada seluruh cabang olahraga untuk mencapai prestasi yang tinggi (Apriansyah et al., 2017). Berdasarkan hal tersebut maka komponen fisik kecepatan akan berpengaruh terhadap keterampilan bermain sepakbola melalui motivasi. Pemanfaatan kecepatan dalam permainan sepak bola adalah pada saat bergerak menggiring bola, berlari mengejar bola dan mencari ruang (Paisal, 2018).Penampilan seorang atlet tidak bisa dilepaskan dari daya dorong yang miliki. Sederhananya, semakin besar daya dorong yang dimiliki, maka penampilan akan semakin optimal, tentu saja jika ditunjang dengan kemampuan teknis dan kemampuan fisik yang memadai. Daya dorong itulah yang biasa disebut dengan motivasi (Prabowo, 2016).

Berdasarkan Tabel 7, untuk Hipotesis 16, pengujian Nilai koefisien terlihat bahwa variabel keseimbangan (X5) 0,063 atau sebesar 6\%, secara statistik memliki pengaruh yang signifikan terhadap variabel keterampilan bermain sepakbola (Y) melalui motivasi $(\mathrm{X})$ yang ditunjukkan oleh nilai sig. lebih kecil dari Alpha 5\% yaitu 0,000. Terdapat pengaruh keseimbangan terhadap keterampilan bermain sepakbola melalui motivasi berlatih sebesar 6\%. Keseimbangan berkembang melalui proses latihan secara berulang-ulang serta terkadang dalam waktu yang lama, untuknya itu haruslah melalui motivasi berlatih yang tinggi. Motivasi berprestasi merupakan suatu dorongan yang sangat terkait dengan bagaimana melakukan sesuatu dengan baik, tepat, dan efisien yang ditandai dengan adanya tendensi untuk meraih kesuksesan dan tendensi untuk menghidari kegagalanuntuk mencapai kesuksesan dalam sebuah 
kompetisi (Fallo \& Lauh, 2017). Motivasi sangat erat kaitannya dengan kinestetik (gerak), karena itu tingkat kinestetik yang dimiliki siswa tinggi akan dapat mendorong siswa dalam proses pembelajaran serta selalu berupaya untuk mencapai hasil yang optimal dan berprestasi(Syahruddin et al., 2019)

\section{SIMPULAN}

Informasi baru kepada pembina UKM Olahraga Sepakbola UM Palopo yang dihasilkan melalui penelitian ini yaitu tentang gambaran komponen fisik, motivasi berlatih, dan keterambilan bermain atlet UKM Olahraga Sepakbola. Terkhusus komponen fisik yakni kelentukan (X1) yang juga sebagai novelty dalam penelitian ini adalah komponen fisik yang penting untuk diperhatikan mengingat kehalusan gerak, keluwesan gerak, lancar dan tidak kaku adalah syarat untuk menghasilkan keterampilan bermain sepakbola yang maksimal. Berdasarkan hasil penelitian maka Pembina UKM Olahraga Sepakbola memperhatikan komponen fisik sebagai faktor yang harus masuk dalam agenda program latihan serta berupaya untuk menjaga motivasi berlatih atlet.

Penelitian dapat dilakukan secara daring, tentunya dengan penggunaan dan pengembangan media (e-learning UM Palopo dan Google Form) dan komitmen yang tinggi dari semua pihak. Penelitian dalam masa Pendemic dengan pembatasan tertentu dapat dijalankan secara daring tentunya dengan penggunaan dan pengembangan media, adapun dalam penelitian ini menggunakan media aplikasi $e$ learning UM Palopo (Gambar 2) dan aplikasi Google Form (Gambar 3) tentunya komitmen yang tinggi dari semua pihak.

\section{DAFTAR PUSTAKA}

Adil, A., Tangkudung, J., \& Hanif, A. S. (2018). The influence of speed, agility, coordination of foot, balance and motivation on skill of playing football. Jipes - Journal of Indonesian Physical Education and Sport, 4(1), 19-34. https://doi.org/10.21009/JIPES.041.02

Aditya, K., Putra, D., Yoda, I. K., Sudarmada, I. N., \& Ganesha, P. (2016). Pengaruh pelatihan slalom dribbling terhadap kelincahan dan VO2Maks siswa peserta ekstrakurikuler sepak bola. Jurnal Ilmu Keolahragaan Undiksha, 5(1), 1-11. https://doi.org/10.23887/jiku.v4i2.7896

Ambarwati, D. R., Widiastuti, W., \& Pradityana, K. (2017). Pengaruh daya ledak otot lengan, kelentukan panggul, dan koordinasi terhadap keterampilan tolak peluru gaya O’Brien. Jurnal Keolahragaan, 5(2), 207. https://doi.org/10.21831/jk.v5i2.14918

Apriansyah, B., Sulaiman, S., \& Mukarromah, S. B. (2017). Kontribusi motivasi, kerjasama, kepercayaan diri terhadap prestasi atlet sekolah sepakbola Pati Training Center di Kabupaten Pati. Journal of Physical Education and Sports, 6(2), 101-107. https://journal.unnes.ac.id/sju/index.php/jpes/article/view/17358

Blegur, J., \& Mae, R. M. (2018). Motivasi berolahraga atlet atletik dan tinju. Jurnal Keolahragaan, 6(1), 29-37. https://doi.org/10.21831/jk.v6i1.16150

Bryson, J., Burke, Y., Chang, J. M., Defrantz, A. L., Easton, J., Evans, J., Florence, P., Graziano, B., Johnson, R., Kindel, M., Larkin, T., Miller, C. D., O 'malley, P., Payden, J., Quinn, A., Sanchez, F., Ueberroth, P., Vasquez, G., Wolper, D. L., ... Zachazewski, P. T. (2012). Soccer coaching manual. LA84 Foundation.

Efendi, A. R., Pahliwandari, R., \& Arifin, Z. (2018). Pengaruh latihan kelincahan terhadap kemampuan menggiring dalam permainan sepakbola mahasiswa UKM Sepakbola IKIP PGRI Pontianak. Jurnal Pendidikan Olahraga, 7(1), 1-10. https://doi.org/10.31571/jpo.v7i1.875

Fallo, I. S., \& Lauh, W. D. A. (2017). Motivasi berprestasi atlet futsal IKIP PGRI Pontianak. Jurnal Pendidikan Olahraga, 6(2), 104-118. https://doi.org/10.31571/jpo.v6i2.667

FIFA. (2016). Youth football. Www.FIFA.Com.

Habibie, M., Widiastuti, W., \& Nuriani, S. (2019). Pengaruh metode latihan dan kordinasi mata - kaki terhadap keterampilan shooting dalam sepakbola. Multilateral Jurnal Pendidikan Jasmani Dan Olahraga, 18(1), 25-31. https://doi.org/10.20527/multilateral.v18i1.6564

Hadi, R. (2019). Pengaruh metode latihan dan motivasi berprestasi terhadap keterampilan teknik dasar futsal. Sains Olahraga: Jurnal Ilmiah Ilmu Keolahragaan, 3(2), 108.

https://doi.org/10.24114/so.v3i2.15201 
Hamdi, A., Sultan, A., Susandi, B., \& Wahyudi, E. (2019). Profil kemampuan teknik dasar sepakbola terhadap siswa SMP Negeri 2 Kasimbar. Tadulako Journal Sport Sciences And Physical Education, 7(1), 103-113. http://jurnal.untad.ac.id/jurnal/index.php/PJKR/article/view/12918

Hartanto, D., Amrullah, R., \& Sastaman, P. (2017). Perbedaan pengaruh latihan massed practice, distributed practice, dan koordinasi matakaki terhadap kemampuan passing mendatar sepakbola. Jurnal Pendidikan Olahraga, 6(1), 33-41. https://doi.org/10.31571/jpo.v6i1.572

Hartati, H., \& Ryansyah, D. (2019). Hubungan keseimbangan dan koordinasi mata kaki terhadap hasil dribbling menggunakan kaki bagian luar pada kegiatan ekstrakurikuler futsal. Altius : Jurnal Ilmu Olahraga Dan Kesehatan, 6(1), 25-30. https://doi.org/10.36706/altius.v6i1.8223

Hidayat, A., Imanudin, I., \& Ugelta, S. (2019). Analisa kebutuhan latihan fisik pemain sepakbola dalam kompetisi AFF U-19 (Studi analisis terhadap pemain gelandang Timnas Indonesia U-19). Jurnal Terapan Ilmu Keolahragaan, 4(1), 25-28. https://doi.org/10.17509/jtikor.v4i1.10140

Hiskyia, H. J. (2017). Pengaruh eksplosif power, kelentukan dan motivasi terhadap keterampilan lompat jauh pada siswa SMPN 1 Bajeng Kabupaten Gowa. Universitas Negeri Makassar.

Kurniawan, P. B., Pramono, H., \& Fakhruddin. (2016). Pengaruh metode pembelajaran kooperatif dan motivasi belajar siswa terhadap hasil belajar sepakbola. Journal of Physical Education and Sport, 5(1), 32-40. https://journal.unnes.ac.id/sju/index.php/jpes/article/view/13278

Maliki, O., Hadi, H., \& Royana, I. F. (2017). Analisis kondisi fisik pemain sepakbola Klub PERSEPU UPGRIS Tahun 2016. Jendela Olahraga, 2(2), 1-8. https://doi.org/10.26877/jo.v2i2.1696

Maryono, Rahayu, S., \& Rustiana, E. R. (2017). Metode latihan kelincahan dan fleksibilitas pergelangan kaki terhadap keterampilan menggiring bola. Journal of Physical Education and Sports, 6(1), 66-71. https://journal.unnes.ac.id/sju/index.php/jpes/article/view/17324

Nasirudin, Y., Gde Purwa Samatra, D. P., Wahyuddin, W., Purnawati, S., Linawati, N. M., \& Sugijanto, S. (2017). Trunk balance exercise lebih baik dari pada strengthening back exercise dalam meningkatkan keseimbangan kinerja otot erector spine pada pemain futsal pemula. Sport and Fitness Journal, 5(3), 118-124. https://doi.org/10.24843/spj.2017.v05.i03.p16

Paisal, P. (2018). Pengaruh kecepatan, koordinasi mata kaki dan motivasi terhadap keterampilan menggiring bola dalam permainan sepakbola pada pemain Ponrang FC Kabupaten Luwu [Universitas Negeri Makassar]. http://eprints.unm.ac.id/10998/

Prabowo, B. Y. (2016). Pengaruh latihan bench press dan motivasi terhadap kemampuan tolak peluru. Jurnal Keolahragaan, 4(2), 135. https://doi.org/10.21831/jk.v4i2.10891

Pratama, A., \& Imanudin, I. (2019). Aerobic capacity (VO2Max) dan jarak tempuh pemain sepak bola. Jurnal Terapan Ilmu Keolahragaan, 3(2), 12-16. https://doi.org/10.17509/jtikor.v3i2.10132

Rahmansyah, B., Jufrianis, J., \& Tangkudung, J. (2018). The effects of explosive limb muscle strength, eye-foot coordination and self-confidence in shooting skills. Jipes - Journal of Indonesian Physical Education and Sport, 4(2), 61-70. https://doi.org/10.21009/JIPES.042.09

Ridwan, M. (2016). Pengaruh keseimbangan, kelincahan dan motivasi berolahraga terhadap keterampilan passing atas bola voli di SMA Negeri 1 Panggarangan Kabupaten Lebak. Multilateral Jurnal Pendidikan Jasmani Dan Olahraga, 15(1), 86-100. https://doi.org/10.20527/multilateral.v15i1.2486

Rosita, T., Hernawan, H., \& Fachrezzy, F. (2019). Pengaruh keseimbangan, kekuatan otot tungkai, dan koordinasi terhadap ketepatan shooting futsal. Jurnal Terapan Ilmu Keolahragaan, 4(2), 117 126. https://doi.org/10.17509/jtikor.v4i2.18991

Sakti, B. P. I. (2017). Hubungan koordinasi mata-kaki dan kelincahan dengan keterampilan menggiring bola dalam permainan sepakbola pada siswa ekstrakurikuler SMA Negeri 2 Lubuklinggau. Biormatika: Jurnal Ilmiah Fakultas Keguruan Dan Ilmu Pendidikan, 3(2), 140146. http://www.ejournal.unsub.ac.id/index.php/FKIP/article/view/107

Suprayitno, S., \& Damanik, S. A. (2016). Keterampilan teknik dasar sepakbola dapat dipengaruhi oleh kemandirian siswa, dukungan orang tua dan motivasi berprestasi. Jurnal Ilmu Keolahragaan, 15(1), 1-10. https://doi.org/10.24114/jik.v15i1.6117 
Jurnal Keolahragaan 8 (2), 2020 - 139

Firmansyah Dahlan, Rahmad Hidayat, Syahruddin Syahruddin

Supriyono, E. (2018). Pengembangan aplikasi tes keterampilan sepakbola berbasis web. Jurnal Keolahragaan, 6(1), 38-47. https://doi.org/10.21831/jk.v6i1.12764

Syahruddin, S., Saleh, M. S., \& Saleh, M. S. (2019). The influence of kinesthetics, attitude and motivation on the learning results of sports education. Jurnal SPORTIF : Jurnal Penelitian Pembelajaran, 5(2), 232. https://doi.org/10.29407/js_unpgri.v5i2.12871

Syarif, S., \& Suardi, S. (2019). Pengaruh metode latihan dan koordinasi mata-kaki terhadap kemampuan menggiring bola pada permainan sepakbola siswa SMA Negeri 1 Anggeraja Kabupaten Enrekang. SPORTIVE: Journal Of Physical Education, Sport and Recreation, 2(2), 18. https://doi.org/10.26858/sportive.v2i1.9399

Utama, A. Z., Hariyanto, E., \& Sudjana, I. N. (2015). Pengaruh latihan kelincahan dan kelentukan terhadap keterampilan dribbling sepakbola SSB PAS-ITN Kabupaten Malang. Jurnal Pendidikan Jasmani, 25(1), 31-38. https://doi.org/10.17977/pj.v25i1.4887.g1286

Yang, Z. (2014). Study on classification of football techniques and the analysis on factors influencing football techniques. BioTechnology An Indian Journal, 10(21), 13033-13037.

Zainur, Z., \& Sulastio, A. (2019). Kontribusi kekuatan otot tungkai dan koordinasi mata-kaki terhadap akurasi tendangan ke gawang. Journal Sport Area, 4(1), 279.

https://doi.org/10.25299/sportarea.2019.vol4(1).3016 